\title{
The influence of open space on the sustainable development of a residential area: three time periods - three case studies in the City of Brno (Czech Republic)
}

\author{
M. Wittmann, M. Kristof \& S. Kubinova \\ Faculty of Architecture, Brno University of Technology, Czech Republic
}

\begin{abstract}
The factors influencing the sustainable development of housing include the properties of open spaces, understood as undeveloped land between residential buildings. The size of the open space, the amount of greenery, the spatial arrangement, the height of the surrounding buildings and many other factors influence the quality of the environment. These and other properties of the space influence the ecological stability of the area, its hygiene qualities, its use by various social groups and also the value of the surrounding real estates. These qualities indicate the environmental, social and economic sustainability of the area. The proposed research methodology assesses specific indicators of sustainability within a range from 0 to 10 points. Five points correspond to the general standard in the area, 0 points indicates degradation, and 10 points indicates the greatest possible contribution to sustainable development. Observation methods, methods of questionnaire research, statistical analyses, and methods of measurement are used to determine the values of the given indicators. The mutual relationship between the properties of the residential structure, its open space and indicators of sustainability can be demonstrated by analyses of case studies. The methodology is verified by them. Three forms of residential structures in the City of Brno in the Czech Republic were selected for analysis - the courtyard of a building from the 19th century, areas in the panel housing estate constructed under socialism in the 20th century, and a courtyard in a new residential building from the beginning of the 21 st century.

Keywords: sustainable development, residential structure, the open space, case studies, historical building, panel housing estate.
\end{abstract}




\section{Introduction: the importance of open space for sustainable urban development}

According to the assumption, quality of life in cities and sustainable development of housing are - among others - influenced by properties of open space, which can be defined as an area without above-ground structures, or an area amidst residential buildings and around them. The size of the open space, the amount and characteristics of greenery, the spatial layout and the accessibility of the space, the surrounding structures and their height, as well as many other properties affect the quality of the environment and the quality of life of the residents. The above mentioned, as well as other properties of the space affect the ecological stability of the area (for example biodiversity) and its hygienic properties (for example temperature and microclimate), as described, for example, by Bowler et al. [1]. Properties of the space also affect the intensity and way of use by various social groups, and - also in line with the assumption - the price of land and of the surrounding properties.

The nature and properties of open space thus affect the quality of the environment and life. Open space defined by the character of the urban structure co-creates the potential for sustainable development of urbanized areas.

As a standard, sustainable development of an area is evaluated in the pillars of sustainability. Environmental indicators of sustainability of an urbanized area especially include ecological and hygienic indicators. Ecological indicators indicate - among others - the level of the natural development of biological components and the level of nature self-regulation; hygienic indicators indicate in particular - the quality of living conditions of man.

Social sustainability stems from demographic parameters of the society and also from the continuity of social standards. Social sustainability in the open, often public space manifests itself by a diversified community of residents and visitors, the stability of which varies. The space allows for social interaction; in terms of vitality, it has considerable, symbolic importance, as stated by Varna and Tiesdell [2]. Quality of living conditions formed by the space is then indicated by a feeling of security and by attractiveness of the space for people, as evidenced by many examples [3]. Social indicators also provide a reflection to the environmental and economic quality of the area.

Economic indicators of the sustainability of an urbanized area reflect its economic stability, balance and reasonable growth of consumption and production. The indicators may not be completely in line with price movements acceptable by users and residents, and this only confirms the necessity of such an analysis to be followed by the prediction of alternative development, as stated by Wheeler [4]. People make decisions on investing in housing or business once or twice in a lifetime and while doing so, consider many aspects of life in the city, as stated by Friedman [5].

The said quality of the environment and of the space as a whole indicates environmental, social and economic sustainability of open space and of the related urbanized area. They constitute the subject of a research project The Importance of Open Space for Sustainable Urban Development. 
Within the research project, methodology for examining the impact of the environment and open space on sustainable development was designed. This text presents the first goal of the research project: verification of the methodology on pilot case studies. Three typical residential structures in the city of Brno were chosen. Each of them represents a different historical period and a different urban concept. The verification of the methodology consists in recognizing valid indicators of sustainability, which arise from differences of residential structures surveyed, as well as from opinions of the residents. Important indicators and information are broken down in the text. Special attention is paid to a residential structure in a panel housing estate, which represents a specific form of housing especially in post-socialist countries. Uncertain development was predicted for panel housing estates, with the possibility of their transformation into socially excluded locations.

\section{Indicators of sustainability: research methodology}

The research project aims - as its ultimate goal - to identify some relations between characteristics of open space and selected sustainability indicators. In addition to the space location in relation to the city and its transport systems, the basic groups of characteristics also include its spatial and aesthetic properties, the nature of surrounding structures, the use of the space and its amenities, as well as the socio-economic context that includes parameters of the society and ownership relations.

Within the methodology elaborated by Kopacik [6] in the form of a table multicriteria analysis, indicators of sustainability are evaluated in the range of $0-10$ points. Five points correspond to a usual standard in the area, 0 points means degradation, and 10 points the maximum contribution for sustainable development. Some indicators are evaluated only in the range of $0-5$ points; these are phenomena the essence of which always degrades the potential of sustainability. This may include, for example, acts of vandalism in the location. If the level of the phenomenon is not detected or if it is absent, points are not assigned to the indicator and it keeps the value 5. Indicators of sustainability are included in the tables for a clear comparison. Indicators that are not given points in the table (see Section 4 Survey evaluation) remain uncoloured. Detailed definitions of point-giving to the indicators are not included in this text because of the scope.

Selected indicators of sustainability are reviewed within four main groups pillars: ecology, hygiene, society, and economics. The main groups also include the so-called framework aggregated indicators. The value of the sustainability pillar in a particular case study is obtained as a sum of the so-called weighted points, which express the conversion of point evaluation of a partial indicator using its sub-weight. The sum of sub-weights is equal to the weight and to the maximum point value of the pillar.

To determine the values of selected and identifiable indicators, the following methods were used: the observation, the method of questionnaire survey among the residents of related houses, the statistical analysis, the analysis of real estate prices, and the methods of measurement and local investigation. 
From the group of ecological indicators, which at the same time contribute to the basic character of the area, indicators related to the size and quality of an ecologically valuable area are relatively easily observable. They can be determined by simple examination on site.

Within the hygiene indicators, temperature and humidity are surveyed by simultaneous measurement at two sites, in the courtyard and in the street. In fact, it is the confirmation of already published findings on a positive impact of tree species and plants on living conditions in urbanized areas as described, for example, by Armson et al. [7]. The equivalent and maximum level of noise is also detected by simultaneous measurement at two sites. Insolation, wind reduction, the presence of smells and of other phenomena are analyzed using knowledge from the observation and using questionnaires designed for the residents of surrounding houses.

Social indicators are partially evaluated on the basis of data obtained from the Czech Statistical Office [8], which provides information about residential buildings related to the open space under research and about the so-called basic residential units, in which these houses are located. Information about the numbers of residents is acquired from the census in 2001 and 2011, and the data on the age structure, the economic activity and education from the census in 2011. The numbers of visitors to the space, etc., are determined by observation. Feeling of security and feeling of home, etc., are ascertained through questionnaires.

Economic indicators are evaluated mainly on the basis of data provided by the real estate agency, Real Spektrum Inc. [9], which prepared the data on prices and rents in specific houses. These are compared with prices in the city (5 points assigned to an indicator means the same value; 10 points means the maximum growth, and 0 points the minimum decrease). Use of apartments and commercial premises, costs of open space upkeeping and the condition of the space are determined by local investigation.

Three forms of arrangement of residential structures in the city of Brno in the Czech Republic were chosen for the pilot survey; each represented a different historical period. The following were analyzed: the courtyard in the block of buildings from the 19th century; the courtyard in the panel housing estate from the period of socialism in the 20th century; and the contemporary courtyard in new, low-rise residential buildings from the early 21 st century.

\section{Case studies}

\subsection{Apartment buildings and a courtyard from the 19th century in the centre of Brno (B19)}

The first area surveyed consists of a courtyard and surrounding five-storey apartment buildings from the second half of the 19th century; the area is marked with a code B19. It is a fully enclosed, publicly inaccessible courtyard demarcated by houses in the central zone of the city of Brno. The houses are owned by the residents, the land of the courtyard is owned by the city. The location is a popular place of living undergoing continuous renewal. The area is directly connected to 
public transport and offers very good civic amenities. Property prices in area B19 significantly exceed average prices in the city of Brno. For a thorough economic analysis, a similar reference structure was also chosen (B19x), which does not have an open space - a courtyard. Prices of apartments there are lower than in area B19.

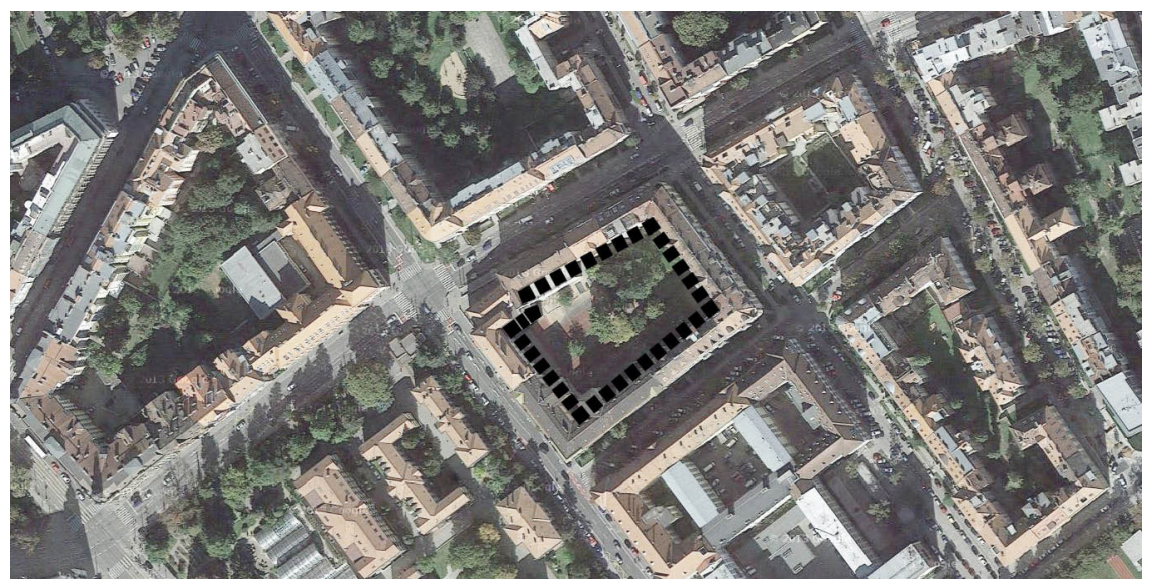

Figure 1: $\quad$ Map of area B19 (B19x).

\subsection{A courtyard in the panel housing estate Brno Vinohrady from the 20th century (B20)}

The second area surveyed is located in a panel housing estate Brno-Vinohrady, completed in the period of socialism in the second half of the $80 \mathrm{~s}$ of the 20 th century. The surveyed area is marked with a code B20. It consists of a courtyard surrounded by two residential houses, one is a four-storey house with privately

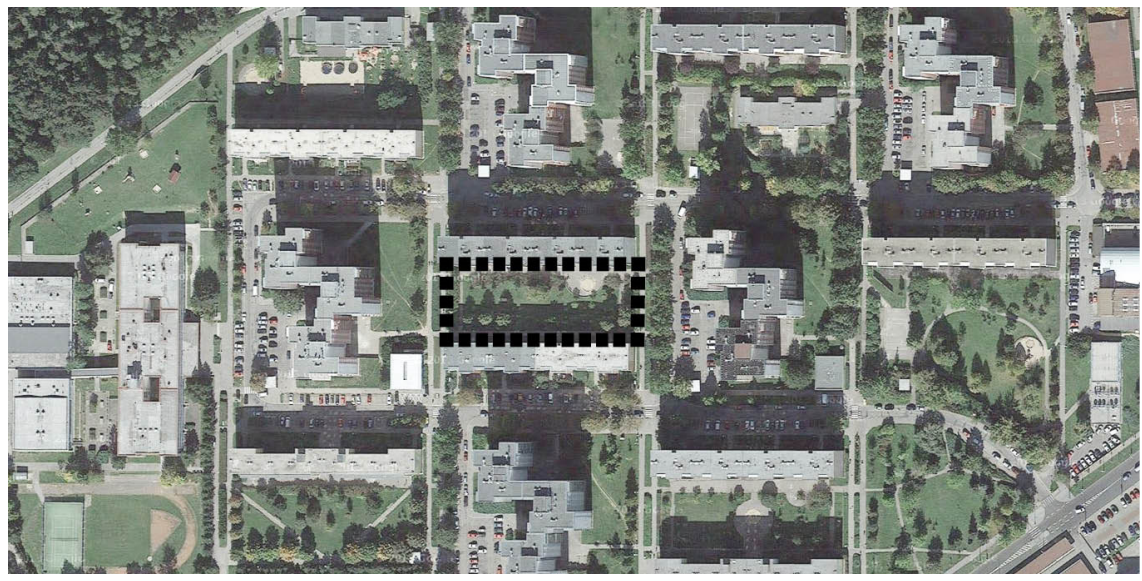

Figure 2: $\quad$ Map of area B20.

WIT Transactions on Ecology and The Environment, Vol 204, (c) 2016 WIT Press www.witpress.com, ISSN 1743-3541 (on-line) 
owned apartments, and the second is an eight-storey house owned by the city. The housing estate is designed as an open system of houses and numerous public spaces, which are not clearly demarcated in terms of space, functionality and use. All free land is owned by the city. Living in the housing estate is currently quite sought after, especially due to rich civic amenities and good quality of affordable apartments. The weakness of the estate is the lack of parking areas.

\subsection{A courtyard in a new residential complex from the 21 st century (B21)}

The third place surveyed is a courtyard in a new residential estate completed at the beginning of the 21st century. The case study is marked as B21. The new residential complex Za Knezskym hajkem represents a sought-after housing on the outskirts of the city, and is located in the Brno-Zebetin city district. The courtyard is surrounded by three-storey blocks of flats in cooperative ownership with builtin parking. The courtyard with land in cooperative ownership is spatially demarcated to the maximum extent by neighbouring houses, but also allows public access.

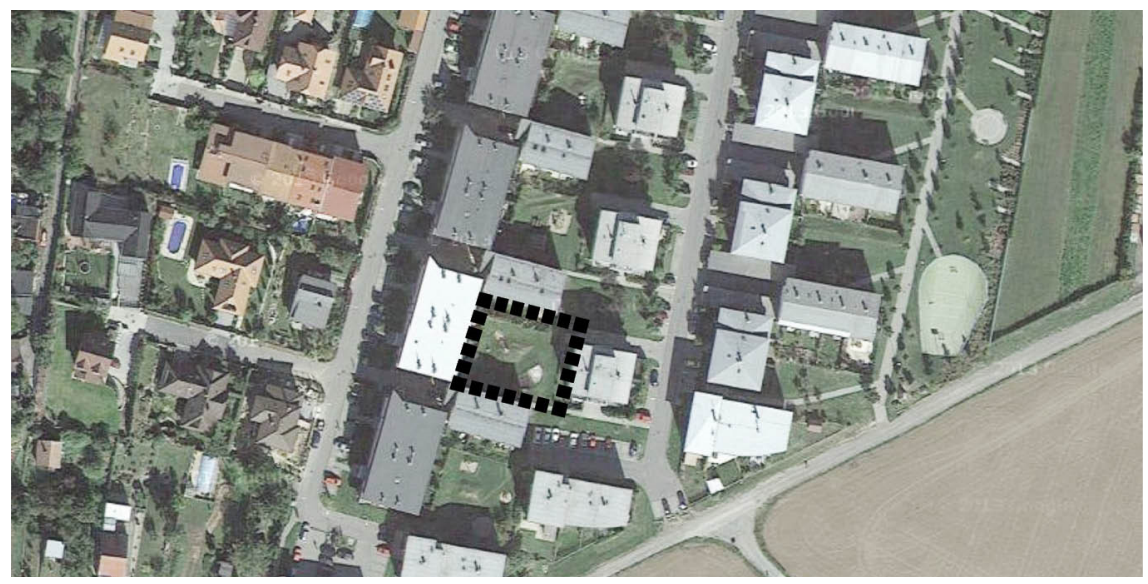

Figure 3: $\quad$ Map of area B21.

\section{Survey evaluation}

Table 1 presents the points received (scoring) by partial indicators of sustainability, the weight of these indicators, the weight and the (weighted) point value of the pillars of sustainability.

\subsection{Ecology}

\subsubsection{Houses in the centre (B19), panel housing estate (B20) and new housing (B21)}

Case studies in the case of a courtyard among historic buildings (B19) and in the case of a courtyard in the panel housing estate (B20) exhibit overall slightly above- 
Table 1: $\quad$ Table of indicators.

\begin{tabular}{|c|c|c|c|c|c|c|}
\hline $\begin{array}{l}\text { Pillar/ } \\
\text { weight/ } \\
\text { weighted } \\
\text { points }\end{array}$ & $\begin{array}{l}\text { Framework } \\
\text { aggregated } \\
\text { indicator }\end{array}$ & Weight & Partial indicator & points & $\begin{array}{c}\text { points } \\
\text { B20 }\end{array}$ & points \\
\hline \multirow{2}{*}{$\begin{array}{c}\text { Ecology } \\
10\end{array}$} & \multirow{4}{*}{$\begin{array}{l}\text { Size of } \\
\text { ecologically } \\
\text { valuable area }\end{array}$} & 1.67 & size & 4.0 & 5.0 & 3.0 \\
\hline & & 0.83 & $\begin{array}{l}\text { interaction with the surroundings - } \\
\text { vegetation }\end{array}$ & 2.0 & 8.0 & 4.0 \\
\hline 5.83 & & 0.83 & $\begin{array}{l}\text { interaction with the surroundings - } \\
\text { water }\end{array}$ & 5.0 & 5.0 & 5.0 \\
\hline 5.61 & & 1.67 & shape & 8.0 & 5.0 & 6.0 \\
\hline \multirow[t]{10}{*}{4.82} & \multirow{10}{*}{$\begin{array}{l}\text { Quality of } \\
\text { ecologically } \\
\text { valuable area }\end{array}$} & 0.45 & $\begin{array}{l}\text { biodiversity of desirable tree } \\
\text { species }\end{array}$ & 6.0 & 4.0 & 9.0 \\
\hline & & 0.45 & age of desirable tree species & 5.0 & 6.0 & 2.0 \\
\hline & & 0.45 & $\begin{array}{l}\text { occurrence of undesirable tree } \\
\text { species }\end{array}$ & 10.0 & 10.0 & 10.0 \\
\hline & & 0.45 & occurrence of undesirable herbs & 10.0 & 9.0 & 10.0 \\
\hline & & 0.45 & desirable animals living in the wild & 3.0 & 3.0 & 1.0 \\
\hline & & 0.45 & ability to collect rainwater & 5.0 & 4.0 & 4.0 \\
\hline & & 0.45 & natural quality of water area & 5.0 & 5.0 & 5.0 \\
\hline & & 0.45 & naturalness of bank zones & 5.0 & 5.0 & 5.0 \\
\hline & & 0.45 & aquatic animals living in the wild & 5.0 & 5.0 & 5.0 \\
\hline & & 0.91 & density of vegetation & 5.0 & 6.0 & 5.0 \\
\hline
\end{tabular}

\begin{tabular}{|c|c|c|c|c|c|c|}
\hline \multirow{2}{*}{$\begin{array}{c}\text { Hygiene } \\
25\end{array}$} & Temperature & 1.92 & reduction of temperature extremes & 6.0 & 6.0 & 4.0 \\
\hline & humidity & 1.92 & reduction of humidity extremes & 9.0 & 7.0 & 7.0 \\
\hline 15.70 & \multirow[t]{2}{*}{ Sun } & 0.96 & reduction of sunburn in summer & 6.5 & 4.0 & 5.0 \\
\hline 15.01 & & 0.96 & $\begin{array}{l}\text { reduction of insolation outside } \\
\text { summer }\end{array}$ & 2.0 & 4.0 & 4.0 \\
\hline \multirow[t]{12}{*}{15.80} & Wind & 1.92 & reduction of windiness & 7.5 & 7.5 & 7.5 \\
\hline & Dust & 1.92 & dust control & 9.0 & 7.0 & 7.5 \\
\hline & \multirow[t]{5}{*}{ Noise } & 1.28 & level of acoustic pressure & 7.1 & 6.0 & 7.0 \\
\hline & & 0.64 & $\begin{array}{l}\text { reduction of external noise from } \\
\text { traffic }\end{array}$ & 10.0 & 7.5 & 7.0 \\
\hline & & 0.64 & $\begin{array}{l}\text { noise nuisance from the } \\
\text { neighbourhood }\end{array}$ & 4.3 & 4.1 & 3.9 \\
\hline & & 0.64 & local noise nuisance & 3.7 & 3.9 & 3.3 \\
\hline & & 0.64 & pleasant natural sounds & 7.0 & 7.0 & 7.0 \\
\hline & \multirow[t]{2}{*}{ Smells } & 0.96 & local smell nuisance & 4.0 & 4.1 & 4.4 \\
\hline & & 0.96 & pleasant natural smell & 7.0 & 6.0 & 6.0 \\
\hline & Insects & 1.92 & rate of insect nuisance & 4.3 & 4.0 & 4.7 \\
\hline & Cleanliness & 3.85 & cleanliness of the space & 5.5 & 7.0 & 10.0 \\
\hline & $\begin{array}{l}\text { Other } \\
\text { pollutants }\end{array}$ & 3.85 & limitation of chemical pollutants & 6.0 & 6.0 & 5.0 \\
\hline
\end{tabular}


Table 1: $\quad$ Continued.

\begin{tabular}{|c|c|c|c|c|c|c|}
\hline $\begin{array}{l}\text { Pillar/ } \\
\text { weight/ } \\
\text { weighted } \\
\text { points }\end{array}$ & $\begin{array}{l}\text { Framework } \\
\text { aggregated } \\
\text { indicator }\end{array}$ & Weight & Partial indicator & points & points & $\begin{array}{l}\text { points } \\
\text { B21 }\end{array}$ \\
\hline \multirow{2}{*}{$\begin{array}{r}\text { Society } \\
35\end{array}$} & \multirow{4}{*}{$\begin{array}{l}\text { Demographic } \\
\text { diversity }\end{array}$} & 1.75 & change in the number of residents & 8.0 & 1.0 & 5.0 \\
\hline & & 1.75 & $\begin{array}{l}\text { age structure of the residents } \\
\text { according to the census }\end{array}$ & 3.0 & 3.5 & 1.0 \\
\hline 22.43 & & 1.75 & $\begin{array}{l}\text { age structure of the population } \\
\text { according to the survey }\end{array}$ & 10.0 & 5.0 & 9.0 \\
\hline 18.16 & & 1.75 & gender diversity of space users & 9.6 & 10.0 & 7.0 \\
\hline \multirow[t]{25}{*}{23.50} & Health & 7.00 & subjective health condition & 7.5 & 6.3 & 7.7 \\
\hline & \multirow[t]{12}{*}{$\begin{array}{l}\text { Risk of social } \\
\text { exclusion }\end{array}$} & 0.58 & $\begin{array}{l}\text { educational structure of the } \\
\text { population }\end{array}$ & 8.5 & 4.9 & 10.0 \\
\hline & & 0.58 & median monthly income & 7.5 & 7.5 & 7.5 \\
\hline & & 0.58 & unemployment & 5.6 & 4.0 & 8.5 \\
\hline & & 0.58 & ethnic diversity & 5.0 & 6.0 & 5.0 \\
\hline & & 0.58 & $\begin{array}{l}\text { feeling of danger in the location } \\
\text { during the day }\end{array}$ & 4.1 & 3.0 & 4.8 \\
\hline & & 0.58 & $\begin{array}{l}\text { feeling of danger in the location } \\
\text { during the night }\end{array}$ & 3.6 & 2.3 & 4.3 \\
\hline & & 0.58 & feeling of security in the area & 8.4 & 5.3 & 9.3 \\
\hline & & 0.58 & demonstration of vandalism & 5.0 & 5.0 & 5.0 \\
\hline & & 0.58 & traces of drug abuse & 5.0 & 5.0 & 5.0 \\
\hline & & 0.58 & alcohol-drinking groups & 5.0 & 5.0 & 5.0 \\
\hline & & 0.58 & untrustworthy strangers & 5.0 & 4.1 & 4.9 \\
\hline & & 0.58 & good address & 7.7 & 5.8 & 8.3 \\
\hline & \multirow[t]{7}{*}{ Area use } & 1.00 & diversity of activities & 2.7 & 3.9 & 2.5 \\
\hline & & 1.00 & frequency of activities & 3.8 & 5.6 & 5.2 \\
\hline & & 1.00 & maximum number of visitors & 1.5 & 1.5 & 6.0 \\
\hline & & 1.00 & average number of visitors & 7.8 & 1.5 & 8.0 \\
\hline & & 1.00 & space meets the needs & 6.7 & 4.7 & 5.7 \\
\hline & & 1.00 & $\begin{array}{l}\text { perception of aesthetic quality of } \\
\text { the space }\end{array}$ & 6.5 & 5.4 & 7.5 \\
\hline & & 1.00 & pleasant view & 3.9 & 5.6 & 6.3 \\
\hline & \multirow{5}{*}{$\begin{array}{l}\text { Relation to } \\
\text { the place }\end{array}$} & 1.40 & feeling at home & 7.7 & 5.2 & 8.3 \\
\hline & & 1.40 & perception of changing neighbours & 6.5 & 8.4 & 8.3 \\
\hline & & 1.40 & autochthony & 7.4 & 9.7 & 9.4 \\
\hline & & 1.40 & neighbourly relations & 6.9 & 5.2 & 7.8 \\
\hline & & 1.40 & $\begin{array}{l}\text { participation in maintaining the area } \\
\text { around the house }\end{array}$ & 0.6 & 2.3 & 6.0 \\
\hline
\end{tabular}


Table 1: $\quad$ Continued.

\begin{tabular}{|c|c|c|c|c|c|c|}
\hline $\begin{array}{l}\text { Pillar/ } \\
\text { weight/ } \\
\text { weighted } \\
\text { points }\end{array}$ & $\begin{array}{l}\text { Framework } \\
\text { aggregated } \\
\text { indicator }\end{array}$ & Weight & Partial indicator & $\begin{array}{c}\text { points } \\
\text { B19 }\end{array}$ & points & $\begin{array}{c}\text { points } \\
\text { B21 }\end{array}$ \\
\hline \multirow[t]{2}{*}{ Economics } & \multirow{2}{*}{$\begin{array}{l}\varnothing \text { price of } \\
\text { land }\end{array}$} & 1.75 & \multirow{2}{*}{ building plot } & \multirow{2}{*}{7.5} & \multirow{2}{*}{0.8} & \multirow{2}{*}{1.0} \\
\hline & & 1.75 & & & & \\
\hline \multirow{22}{*}{$\begin{array}{c}30 \\
21.98 \\
16.88 \\
14.89\end{array}$} & \multirow{7}{*}{$\begin{array}{l}\varnothing \text { price of the } \\
\text { building } \\
\text { structure }\end{array}$} & 1.75 & apartment & 7.5 & 4.0 & 4.0 \\
\hline & & 1.75 & shop & 10.0 & 5.0 & 5.0 \\
\hline & & 7.00 & administration & 10.0 & 5.0 & 5.0 \\
\hline & & 0.58 & manufacturing and storage & 5.0 & 5.0 & 5.0 \\
\hline & & 0.58 & built-in parking space & 10.0 & 4.0 & 2.5 \\
\hline & & 0.58 & outdoor parking space & 10.0 & 10.0 & 1.0 \\
\hline & & 0.58 & parking space in a separate garage & 10.0 & 6.7 & 4.0 \\
\hline & \multirow[t]{7}{*}{$\varnothing$ rent } & 0.58 & apartment & 8.7 & 4.2 & 4.5 \\
\hline & & 0.58 & shop & 10.0 & 2.5 & 5.0 \\
\hline & & 0.58 & administration & 6.5 & 2.5 & 5.0 \\
\hline & & 0.58 & manufacturing and storage & 5.0 & 5.0 & 5.0 \\
\hline & & 0.58 & built-in parking space & 10.0 & 5.0 & 5.0 \\
\hline & & 0.58 & outdoor parking space & 10.0 & 6.0 & 1.0 \\
\hline & & 0.58 & parking space in a separate garage & 10.0 & 5.0 & 1.0 \\
\hline & \multirow{2}{*}{$\begin{array}{l}\text { Use of the } \\
\text { building }\end{array}$} & 0.58 & occupancy of apartments & 10.0 & 10.0 & 10.0 \\
\hline & & 1.00 & use of commercial spaces & 10.0 & 10.0 & 5.0 \\
\hline & \multirow{2}{*}{$\begin{array}{l}\text { Cost of } \\
\text { upkeeping }\end{array}$} & 1.00 & upkeeping costs per unit area & 5.0 & 6.0 & 3.0 \\
\hline & & 1.00 & upkeeping costs per resident & 8.2 & 7.2 & 7.0 \\
\hline & \multirow[t]{3}{*}{ Tidiness } & 1.00 & $\begin{array}{l}\text { tidiness and technical condition of } \\
\text { the space }\end{array}$ & 3.5 & 7.5 & 10.0 \\
\hline & & 1.00 & $\begin{array}{l}\text { tidiness and technical condition of } \\
\text { the furnishing elements }\end{array}$ & 5.5 & 6.0 & 8.0 \\
\hline & & 1.00 & $\begin{array}{l}\text { tidiness and condition of the } \\
\text { vegetation }\end{array}$ & 3.5 & 7.5 & 8.0 \\
\hline & $\begin{array}{l}\text { General } \\
\text { economics }\end{array}$ & 1.00 & median monthly income & 5.5 & 5.0 & 5.0 \\
\hline
\end{tabular}

standard ratings in terms of ecology. The area of courtyard B21 is smallest, and in comparison with the space of the enclosed courtyard (B19) exhibits a slightly higher level of ecological interactions with the surroundings. In all cases, the courtyards are well kept up with a usual proportion of vegetation. In the semiprivate courtyard in cooperative ownership (B21), tree species are very diverse.

\subsection{Hygiene}

\subsubsection{Houses in the centre (B19), panel housing estate (B20) and new housing (B21)}

Hygienic conditions in all compared courtyards are above standard. In the case of area B19 it is worth a special mention that the courtyard and the surrounding buildings are able to eliminate outside noise from traffic. Courtyards B19 and B20 
eliminate temperature extremes in the summer months and at the same time increase humidity of air at higher temperatures. The courtyard in the new residential estate (B21) on the one hand generates an increase in air humidity, on the other hand does not eliminate higher air temperature in the summer months. The main reason is its compactness in combination with smaller dimensions, which allows reflections and subsequent concentration of heat in the courtyard. In all the areas, residents of the houses perceive rather positively residential comfort of the courtyards with a more significant exception of insolation conditions outside summer. Some residents in area B21 in the questionnaires directly critically evaluated local noise nuisance. According to the observers, space B21 is cleaner in comparison with the others.

\subsection{Society}

\subsubsection{Historic houses and the courtyard in the centre (B19)}

In the case of the residential structure from the 19th century (B19), the selected social sustainability indicators are very much above standard in the overall scoring. The number of residents is stabilized, with a loss of only $2 \%$ between 2001 and 2011. According to the questionnaire survey (the median of 40 years), the age structure corresponds to the median age in the country. According to the census, the age structure also shows considerable predominance of retired residents over children under the age of 14; the ratio is roughly $2.5: 1$. Unemployment among the residents of the houses in area B19 is below the national average; its value is $4.3 \%$. The share of population with completed qualification higher than elementary education exceeds the national average; it is $92.7 \%$ [8]. The use of the space is reinforced by a strong sense of security. According to the questionnaires, the residents would like to use the space more for various social activities. Neighbourly relations are described as above standard. Unique willingness appeared among the respondents to contribute more financially to the upkeeping of the courtyard, if it was more used by children. In the area of B19, children are not perceived as a source of annoying noise (unlike B21).

\subsubsection{Panel housing estate (B20)}

Panel blocks of flats throughout the panel housing estate suffer from population decline; between 2001 and 2011, this decline in the whole housing estate was $10 \%$ [8]. According to the census, the age structure in the blocks of flats shows a significant predominance of children under 14 years of age compared to seniors; the ratio was roughly $2: 1$, which creates the potential for a strong social control in the public space by parents with children. At the same time, however, this condition leads to significant potential superiority of one generation and consequent risks. The share of the population with completed qualification higher than elementary education in area B20 is roughly at the same level as the national average (about $87 \%$ ) [8]. The space is used by children, but only little. The use of the courtyard is reduced by less security. There are many public spaces in the housing estate. Residents gather at selected public spaces, and rarely visit the others. In the case of area B20, the residents said they would appreciate direct benefit from local greenery. 


\subsubsection{New residential complex (B21)}

The age structure of the population of the houses in the new residential complex (B21) according to the statistics shows an extreme, risky predominance of children over seniors (about 88:12). Unemployment of the residents is lowest of all the areas surveyed, reaching $2.2 \%$. The share of the population with completed qualification higher than elementary education in area B21 is significantly higher than the national average, reaching $94.4 \%$ [8]. The residential structure creates a sense of neighbourhood; according to the respondents, the backyard is perceived as extremely secure. According to the questionnaire survey, some residents feel bothered by the local noise in the area, namely by children.

\subsection{Economics}

Economic parameters of case studies are strongly influenced by the characteristics of the location, which - as a whole - show similar information about prices.

\subsubsection{Historic houses and a courtyard in the city centre (B19)}

Residential structure B19 benefits from its location in relation to the city centre. It is long sought after both by population and entrepreneurs. Selling prices and rents there are higher, exceeding the Brno maximum prices and rents. The selling prices in reference area B19x in the same location as B19 are about 9\% lower [9].

\subsubsection{Panel housing estate (B20)}

Real estate prices in the housing estate are below average. The exception is the price of outdoor parking places, which is above average in case of availability.

\subsubsection{New residential complex (B21)}

Prices of apartments and rents in suburban area B21 are lower than an average in the city. Keeping up the courtyard on cooperative land is paid from the fund to which the residents contribute. In comparison with the cost of keeping up the courtyards on municipal land (B19, B20), the cost recalculated per unit area is higher. The quality of keeping up of B21 is higher compared with B19 and B20.

\section{Summary}

All three areas surveyed provide sought-after housing with differences caused by construction technology, spatial parameters of buildings and urban concept. From the point of view of perception by residents, all courtyards surveyed are beneficial for the quality of life. A courtyard in the houses with a high social potential in the central part of the city (B19) has a particular importance. This importance is influenced by the location characteristics. Local residents perceive the courtyard as a valuable, secure place for resting and social gathering. Due to its enclosed shape and the amount of greenery, it creates significantly better environmental quality in comparison with its immediate surroundings. Hygiene quality of the environment in area B19 is roughly at the same level as in other courtyards surveyed outside the centre. The importance of space B19 is not devaluated by numerous spaces around (as in B20) or by near natural background (as in B21). 
In area B20 surveyed in the panel housing estate with a lower social potential of sustainability, open spaces are very numerous. As indicated in the survey by the residents, these areas should be mutually differentiated and directly used. The interest in living in a panel housing estate is in contradiction with unfavourable prognoses. This is contributed to by its affordability and good-quality amenities. Lower, but still slightly above-standard social potential of sustainability in the housing estate does not affect the relation of the residents to the open space.

Open space in the new residential estate with a high social potential of sustainability (B21) in the suburban location with a quality nature environment is not valued as highly important by the residents despite its hygienic quality, security, etc. The location characteristic of area B21 in the suburbs is different from area B19 in the centre. Compared with areas B19 and B20, direct financial involvement of the residents in keeping up the area in cooperative ownership resulted in higher quality of upkeeping.

Quality of life in cities is predetermined by parameters of the whole location, by its linking to transport services, amenities and urban concept, which includes a system of open spaces. These spaces - if they have enough greenery - influence ecological and hygiene quality of the location, as well as hygiene quality of the environment within the courtyard. In the long term, hygiene parameters affect social sustainability and contribute to the competitiveness of older residential structures. The importance of open space increases with the intensity of use of the area and with decreasing distance to the centre. The intensity of using the area and the smaller distance to the centre cause an increase in property prices. If this growth is accepted by local users, it contributes to the attractiveness of the area and its sustainability. It can be also said that housing prices in an intensely developed area may be lower in the case of a residential structure with a missing courtyard. This observation does not consider other influences in the area.

Opinions of residents of the houses surveyed confirmed that all the three historical periods succeeded in bringing in a concept of sustainable housing, sought after in the long term. Open space as part of residential structures has become an added value of urbanized areas, although its potential is not always fully used (in the panel housing estate). Results of the survey methodology being verified correspond to this observation.

\section{Acknowledgements}

The paper was produced with the support of the project The Importance of Open Space for Sustainable Urban Development. The project (GACR 15-05237S) is supported by the Czech Science Foundation (GACR).

\section{References}

[1] Bowler, D.E., et al., Urban greening to cool towns and cities: A systematic review of the empirical evidence. Landscape and Urban Planning (97), pp. 147-155, 2010.

[2] Varna, G. \& Tiesdell, S., Assessing the Publicness of Public Space. Journal of Urban Design (4), pp. 575-598, 2010. 
[3] Minguet, J. M., Sustainable Urban Landscape. Instituto Monsa de Ediciones: Barcelona, 2008.

[4] Wheeler, S.M., Planning for Sustainability. Routledge: Abingdon, 2013.

[5] Friedman, A., [editor] Walden, J., Sustainable Resilient Development. McGraw-Hill: New York, 2007.

[6] Kopacik, G., Characteristics and indicators of sustainable development of open spaces - methodical tables. Brno University of Technology, Faculty of Architecture: Brno, 2015.

[7] Armson, D., Stringer, P. and Ennos, A.R. The effect of tree shade and grass on surface and globe temperatures in an urban area. Urban Forestry \& Urban Greening (11), pp. 245-255, 2012.

[8] Czech Statistical Office. The demographic structure of residents of selected blocks of flats and basic settlement units according to the census in 2001 and 2011. Czech Statistical Office, 2015.

[9] Real Spektrum, Inc., Economic passport of the city of Brno and selected locations in the city. Real Spektrum, a.s., 2015. 